University of Nebraska - Lincoln

DigitalCommons@University of Nebraska - Lincoln

$1-1-2004$

\title{
Evaluation of a deer-activated bio-acoustic frightening device for reducing deer damage in cornfields
}

\author{
Jason M. Gilsdorf \\ University of Nebraska-Lincoln \\ Scott E. Hyngstrom \\ University of Nebraska-Lincoln \\ Kurt C. Vercauteren \\ USDA-APHIS, kurt.c.vercauteren@usda.gov \\ Greg M. Clements \\ University of Nebraska-Lincoln \\ Erin E. Blankenship \\ University of Nebraska-Lincoln, erin.blankenship@unl.edu
}

See next page for additional authors

Follow this and additional works at: https://digitalcommons.unl.edu/icwdmother

Part of the Environmental Sciences Commons

\footnotetext{
Gilsdorf, Jason M.; Hyngstrom, Scott E.; Vercauteren, Kurt C.; Clements, Greg M.; Blankenship, Erin E.; and Engeman, Richard M., "Evaluation of a deer-activated bio-acoustic frightening device for reducing deer damage in cornfields" (2004). Other Publications in Wildlife Management. 14.

https://digitalcommons.unl.edu/icwdmother/14
}

This Article is brought to you for free and open access by the Wildlife Damage Management, Internet Center for at DigitalCommons@University of Nebraska - Lincoln. It has been accepted for inclusion in Other Publications in Wildlife Management by an authorized administrator of DigitalCommons@University of Nebraska - Lincoln. 


\section{Authors}

Jason M. Gilsdorf, Scott E. Hyngstrom, Kurt C. Vercauteren, Greg M. Clements, Erin E. Blankenship, and Richard M. Engeman 


\title{
Evaluation of a deer-activated bio- acoustic frightening device for reducing deer damage in cornfields
}

\author{
Jason M. Gilsdorf, Scott E. Hygnstrom, Kurt C. VerCauteren, \\ Greg M. Clements, Erin E. Blankenship, and Richard M. Engeman
}

\begin{abstract}
Deer (Odocoileus spp.) can cause substantial damage to agricultural crops, resulting in economic losses for producers. We developed a deer-activated bio-acoustic frightening device to reduce white-tailed deer (O. virginianus) damage in agricultural fields. The device consisted of an infrared detection system that activated an audio component which broadcast recorded distress and alarm calls of deer. We tested the device against unprotected controls in cornfields during the silking-tasseling stage of growth in July 2001. The device was not effective in reducing damage: track-count indices $\left(F_{1,4}=0.02, P=0.892\right)$, corn yield $\left(F_{1,9}=1.27, P=0.289\right)$, and estimated damage levels $\left(F_{1,10}=0.87, P=0.374\right)$ did not differ between experimental and control fields. The size $\left(F_{2,26}=1.00, P=0.380\right)$, location $\left(F_{2,25}=0.39, P=0.684\right)$, and percent overlap $\left(F_{2,25}=0.20, P=0.818\right)$ of use-areas of radiomarked female deer did not differ between during- and after-treatment periods. We concluded that the deer-activated bio-acoustic device was not effective in protecting cornfields in this study; however, the device may be more effective in small areas such as gardens or for high-value crops that do not grow tall enough to offer protective cover.
\end{abstract}

Key words animal damage control, bio-acoustics, corn, distress calls, frightening devices, Odocoileus virginianus, white-tailed deer, wildlife damage management

Damage to agricultural crops can be a problem in areas with high densities of deer (Odocoileus spp.). Deer are responsible for causing more damage to agricultural products than any other species of wildlife (Conover and Decker 1991, Wywialowski and Beach 1992). In the United States, annual economic loss to agricultural producers from wildlife depredation was estimated to be as high as $\$ 4.5$ billion (Conover 2002). In 1993 over \$30 million worth of corn was lost to deer just in the 10 largest corn-producing states (Wywialowski 1996).

Use of corn by deer peaks in late June-early July during the silking-tasseling stage of growth (Hygnstrom et al. 1992). At this stage silk-producing ears emerge from the nodes and pollen-producing tassels emerge from the meristem of the corn plant. Cornfields are highly susceptible to deer damage at the silking-tasseling stage because use by deer is high and this is the most critical period for damage that reduces yield (Eldredge 1935, Shapiro et al. 1986, Vorst 1986). Damaged ears of corn are not replaced and often will become infected with fungus. Producers may be able to reduce expenses and the amount of damage to crops by implementing control methods, such as frightening devices, when corn plants are most susceptible to deer damage.

The duration of protection and efficacy often limits the cost-effectiveness of frightening devices.

Address for Jason M. Gilsdorf, Scott E. Hygnstrom, and Greg M. Clements: School of Natural Resources, 202 Natural Resources Hall, University of Nebraska, Lincoln, NE 68583-0819, USA; e-mail for Gilsdorf: jgilsdorf2@unl.edu. Address for Kurt C. VerCauteren and Richard M. Engeman: USDA/APHIS/WS, National Wildlife Research Center, 4101 LaPorte Avenue, Fort Collins, CO 80521-2154, USA. Address for Erin E. Blankenship: Department of Biometry, 103 Miller Hall, University of Nebraska, Lincoln, NE 68583-0712, USA. 


\section{Wildlife Society Bulletin 2004,32(2):515-523}

Propane exploders, Electronic Guards, and other visual or acoustic devices have been used to control deer damage with variable success (Belant et al. 1996, Curtis et al. 1997, Belant et al. 1998, Gilsdorf et al. 2004). A major limitation of nonlethal frightening devices is that animals habituate to the stimuli (Bomford and O'Brien 1990, Koehler et al. 1990, Craven and Hygnstrom 1994, Nolte 1999). Methods to delay habituation include changing the location of frightening devices and altering the periodicity of stimuli (Koehler et al. 1990, Nolte 1999). Belant et al. (1996) reported that periodically fired propane exploders were effective in frightening deer for $\leq 2$ days, while deer-activated propane exploders were effective for 1-2 weeks. A deeractivated scarecrow device also was effective in reducing deer damage in soybeans for up to 6 weeks (Beringer et al. 2003). Few studies have been published about animal-activated devices.

Use of bio-acoustics as a frightening device is relatively unstudied. Bio-acoustics are animal communication signals, often in the form of alarm or distress calls. An alarm call is a vocalization used to warn other individuals of possible danger, such as the snort from a deer that has sensed a predator (Sauer 1984). A distress call is emitted when an animal is being physically traumatized or restrained (Sprock et al. 1967, Marchinton and Hirth 1984). Most studies using bio-acoustics have been conducted on birds (Thompson et al. 1968, Mott and Timbrook 1988, Aguilera et al. 1991, Gorenzel and Salmon 1993), and knowledge of the potential use of mammalian communication signals for depredation control is scarce (Frings 1964, Koehler et al. 1990). Two potential advantages of bio-acoustics over other acoustic frightening devices (e.g., propane exploders) are that 1) animals may not habituate to them as readily because calls are meaningful to members of the same species and 2) calls may be effective on animals at low intensities; therefore, it is not necessary to produce loud alarm or distress calls that could be disturbing to neighbors or nontarget animals (Frings 1964, Sprock et al. 1967).

Our objective was to design and test a deer-activated bio-acoustic frightening device to reduce white-tailed deer (O. virginianus) damage in cornfields. An extensive literature review (Gilsdorf et al. 2002) prompted us to design a device that incorporated new technology with stimuli that have not been tested. We combined an animal-activation system with a frightening device that emitted deer dis- tress and alarm calls. We conducted our study in an actual field situation to more accurately test the effectiveness of the device in reducing deer damage.

\section{Study area}

We conducted the study during the summer of 2001 at the DeSoto National Wildlife Refuge (DNWR), located $30 \mathrm{~km}$ north of Omaha, Nebraska in the Missouri River valley. The DNWR was a 3,166-ha mosaic of forest, grassland, wetland, and agricultural fields. The density of deer at DNWR was approximately $19 / \mathrm{km}^{2}$, based on previous estimates (VerCauteren 1998) and consistent subsequent harvest rates (DNWR, unpublished data). Corn (156 ha), soybeans (292 ha), grain sorghum, alfalfa, and a wheat/clover mix were cultivated on a 3-year rotation. Approximately 10-16\% of the corn was left standing as food plots for wildlife.

We used cornfields on DNWR as test fields for this study. We located and paired test fields of similar size, shape, and location on the refuge. We used 12 test fields ( 6 pairs) for the study and assigned treatments randomly to each of the fields in a pair. Fields containing the deer-activated bio-acoustic device are referred to as "experimental" while fields with no frightening device are referred to as "control." The average size of the experimental and control fields was 10.9 ha (range $=5.5-19.7 \mathrm{ha}$ ) and 10.7 ha (range $=5.9-15.9$ ha), respectively. The average distance between experimental and control fields was $0.9 \mathrm{~km}$ (range $=0.5-2.9 \mathrm{~km}$ ). The fields were a minimum of $0.5 \mathrm{~km}$ apart to minimize the potential for dependence among the fields. The dimension and shape of the cornfields allowed the frightening devices to protect an average of $30 \%$ (range 21-48\%) of the total perimeter of each experimental cornfield.

\section{Methods}

The deer-activated bio-acoustic device consisted of an infrared detection system and an audio system. We used an outdoor quad-beam infrared security system (model PB-IN200HF, PULNiX Security Sensors Inc., Sunnyvale, Calif.) to detect the presence of deer entering a cornfield. Each system consisted of an infrared transmitting and receiving unit (Figure 1). Four infrared beams were emitted from 4 lenses on the transmitter. We positioned transmitters and receivers horizontally on wooden posts 
50-200 $\mathrm{m}$ apart, aiming the transmitter so that the receiver collected all 4 beams of infrared light. All 4 beams had to be broken simultaneously to activate the audio system. We set the infrared beams 71 $\mathrm{cm}$ aboveground, the height of an average adult deer midway between the top of the back and bottom of the chest (Sauer 1984).

The audio system included a compact disk (CD) player (model CDC-X217, Aiwa, Tokyo, Japan), 30second time delay, relay, counter, and weatherproof 13-cm horn speaker. We suspended each speaker on the edge of a cornfield $2.4 \mathrm{~m}$ above ground with a metal rod. The time-delay device provided power to the CD player for 30 seconds, after which the system reset itself. The counter confirmed that the device was functioning and enumerated the activations. The CD player and other electrical components were contained in a sealed plastic container. Twelve-volt marine batteries powered the frightening devices.

We recorded distress and alarm calls from livecaptured deer with a Sony Digital Handycam (model DCR-TRV320, Sony, Tokyo, Japan). Deer were captured in the study area in netted cage traps and restrained by hand for 1-4 minutes while being equipped with radiocollars. We extracted distress and alarm calls using Video Wave III SE software (MGI Software Corp., Richmond Hill, Ont.), and copied them onto CDs.

We placed 2 frightening devices on the perimeter of each experimental field adjacent to wooded areas where the highest levels of damage were expected. The infrared systems were situated to protect as much field perimeter as possible (50-200 m).

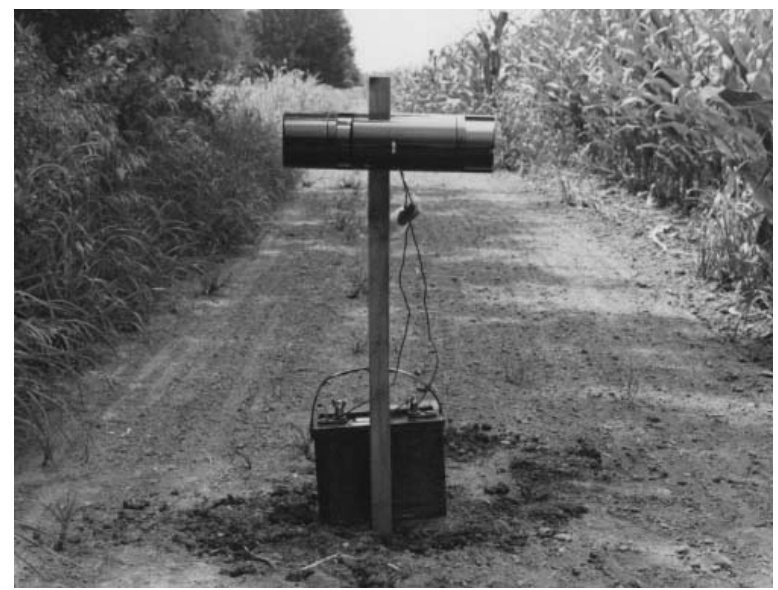

We positioned frightening devices at the first sign of silking-tasseling in the cornfields (6 July 2001) and operated them for 18 days, which was sufficient time for the ears of corn to mature past the silking-tasseling phase and become less attractive and susceptible to deer (Hygnstrom et al. 1992). After the ninth night, devices in each test field were repositioned about $100 \mathrm{~m}$ along the field perimeter to reduce habituation (Koehler et al. 1990, Nolte 1999). We calculated costs of equipment and labor (at $\$ 10 / \mathrm{hr}$ ) required to operate the deer-activated bio-acoustic devices.

We used indices of track counts, corn yields, damage assessments, and use-areas of radiomarked deer to evaluate the efficacy of the frightening devices. A tractor-mounted 2-m-wide drag was used to establish and maintain a smooth dragline around the perimeter of each field. We counted tracks of deer entering and leaving cornfields in the $1 \mathrm{~m}$ of dragline nearest the corn about every 6 days. A single observer counted tracks on all fields to eliminate observer bias. We recorded 1 track count

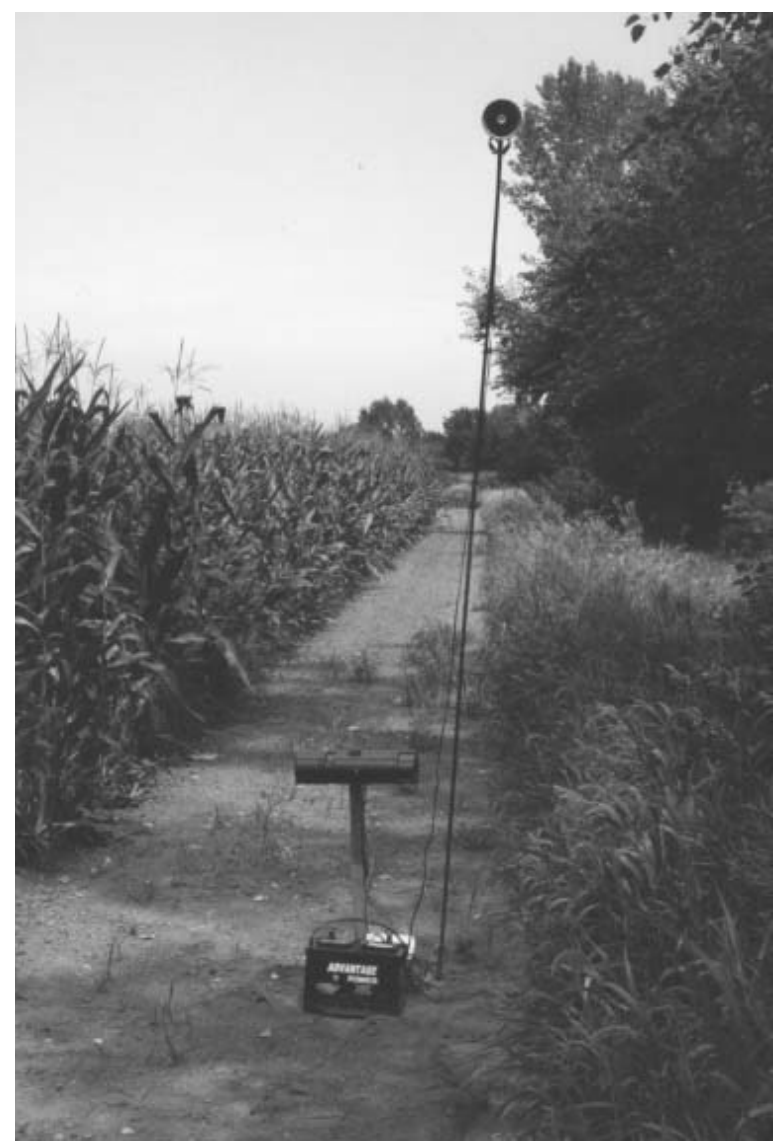

Figure 1. Infrared transmitting unit (left) and receiving unit (right) of the deer-activated bio-acoustic frightening device along the edge of a cornfield. 
before frightening-device application, 2 during the 18-day treatment period, and 3 after the treatment.

We obtained data on corn yield for the 12 test fields from farmers when the corn was delivered to grain elevators or directly from yield monitors linked to Global Positioning Systems (GPS) on their harvesting equipment that calculated yields once every second during harvest. We compared corn yield from experimental fields with those fields that served as controls.

We used a variable-area-transect sampling method (Engeman and Sugihara 1998, Engeman and Sterner 2002) to assess the amount of damage caused by deer in the experimental and control fields immediately following the treatment period. We randomly located 20 test plots in fields $\leq 12.1$ ha and 30 test plots in fields $>12.1$ ha with a numbered grid. At each test plot we inspected a row of corn, counting the total number of ears including damaged and undamaged ears. When 5 deer-damaged ears were tallied, we recorded distance traveled and total number of ears in the row sampled. If 5 deerdamaged ears were not tallied in $100 \mathrm{~m}$, the observer recorded total number of ears and any deer-damaged ears observed in that $100 \mathrm{~m}$ of row. We estimated and compared the average percentage of damage/plot [damaged ears/(damaged ears + undamaged ears)] among fields.

We used chronologically sequenced use-areas of radiomarked female deer associated with the frightening devices to further ascertain effectiveness of the devices. Use-areas were spaces that the radiomarked deer occupied during 2 18-day study periods. We chose to use the term "use-area" rather than "home range" because of the limited time period in which we collected the data. A home range should include all normal activities associated with feeding, resting, mating, and rearing young (Shivik and Gese 2000). We monitored 23 radiomarked deer in the vicinity of the test fields from June-September 2001. Telemetry locations were distributed equally throughout the day and night. We generated use-areas with the Spatial Ecology Analysis System (SEAS), and harmonic mean method (Dixon and Chapman 1980) using a Geographic Information System (TNTmips ${ }^{\circledR}$, MicroImages, Lincoln, Nebr.). Use-areas were defined by the $95 \%$ isopleth, $20 \%$ isopleth core area, and arithmetic center. If the core area was $\leq 0.5 \mathrm{~km}$ from an experimental field or control field, we assigned the deer to the respective treatment.

We produced use-areas with location data from 18-day periods during treatment ("During") and after treatment ("After"). We could not calculate a use-area for the "before treatment" period because of the insufficient number of locations (2-5) recorded per animal. We determined "During" and "After" use-areas with an average of 27 (range $=23-29$ ) and 20 (range =19-22) locations, respectively, for each deer in each period. We evaluated the impact of the frightening device by comparing size, location of center, and percentage overlap of use-areas between during- and after-treatment periods.

We collected data for track-count indices and use-areas over time and analyzed them as repeated measures. We used a randomized complete block design and analyzed the data using a mixed linear model (e.g., McLean et al. 1991), implemented in SAS Proc Mixed (Littell et al. 1996, SAS Institute Inc. 2000) with means estimated as least-squares means. We used Akaike's Information Criterion (AIC) to select the covariance structure that provided the best-fit model for the repeated measures analyses (Littell et al. 1996), and the Kenward-Roger adjustment for denominator degrees of freedom.

All procedures involving animals were approved by the University of Nebraska-Lincoln Institutional Animal Care and Use Committee (IACUC \# 99-03014) and United States Department of Agriculture/ Animal and Plant Health Inspection Service/ Wildlife Services/National Wildlife Research Center Institutional Animal Care and Use Committee (QA726).

\section{Results}

Materials for each deer-activated bio-acoustic device cost about $\$ 600$. The devices we built were prototypes that, to our knowledge, had never been built or tested before. The deer-activated bioacoustic devices needed little maintenance and were functional 24 hours a day during the treatment period. Each device required about one hour to construct and one hour to erect in the field. We estimate it cost $\$ 40-\$ 50 /$ field to deploy the devices.

Analysis of data on track counts showed no differences among the treatment effects $\left(F_{1,4}=0.02, P\right.$ $=0.892)$ and treatment-by-time interaction $\left(F_{5,19}=\right.$ $1.52, P=0.232)$. Differences were detected, however, among time periods $\left(F_{5,19}=77.06, P \leq 0.001\right)$. Use of cornfields by deer tended to decrease similarly in experimental and control fields across the time periods (Figure 2). 


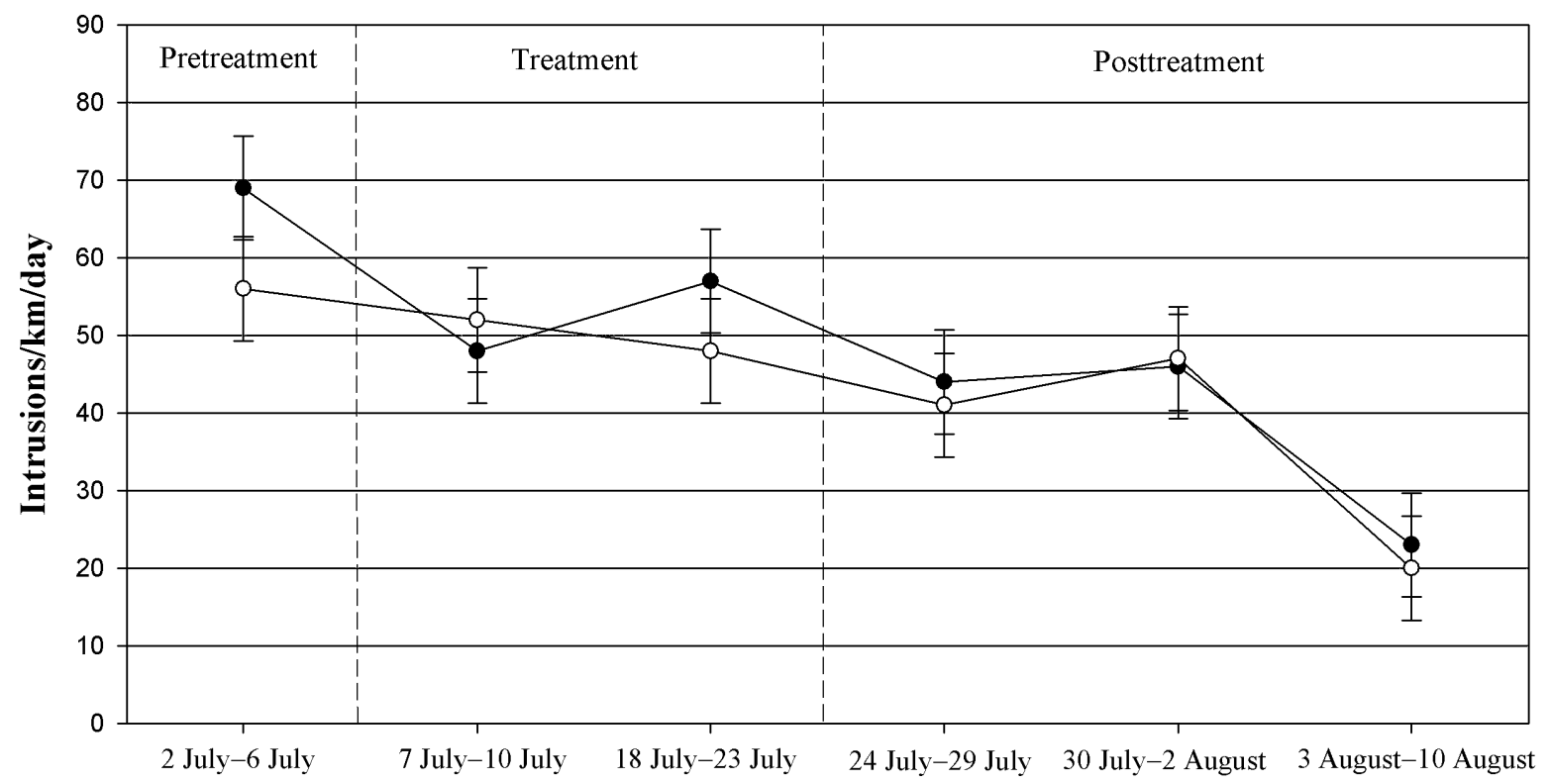

Time

$\longrightarrow$ Deer-activated bioacoustic device

-0 Control

Figure 2. Deer-track counts from perimeters of cornfields protected by deer-activated bio-acoustic frightening device and unprotected (control) fields on DeSoto National Wildlife Refuge, Missouri Valley, lowa, 2001.

The mean yields of corn $(\mathrm{kg} / \mathrm{ha})$ for control $(\bar{x}=$ $5,614, \mathrm{SE}=481, n=6)$ and experimental fields $(\bar{x}=$ $6,381, \mathrm{SE}=481, n=6)$ did not differ $\left(F_{1,9}=1.27, P=\right.$ 0.289). The size of test fields tended to slightly influence the amount of corn produced/hectare $\left(F_{1,9}=3.89, P=0.080\right)$ in that as field size increased, yield (kg/ha) increased.

We found no differences in levels of damage by deer between experimental fields and control fields. The average percentage of damage/plot was not different among experimental $(\bar{x}=20 \%, \mathrm{SE}=4.7$, $n=6)$ and control fields $(\bar{x}=14 \%, \mathrm{SE}=4.7, n=6)$ $\left(F_{1,10}=0.87, P=0.374\right)$.

Table 1. Size and shift of 18-day use-areas of female radiomarked deer exposed to a deer-activated bio-acoustic frightening device on DeSoto National Wildlife Refuge, Missouri Valley, lowa, 2001.

\begin{tabular}{|c|c|c|c|c|c|c|c|c|c|}
\hline \multirow[b]{2}{*}{$\operatorname{Trt}^{\mathrm{C}}$} & \multirow[b]{2}{*}{$n$} & \multicolumn{4}{|c|}{$\bar{x}$ size (ha) } & \multicolumn{2}{|c|}{$\bar{x}$ center shift $(\mathrm{m})^{\mathrm{a}}$} & \multicolumn{2}{|c|}{$\bar{x} \%$ overlap ${ }^{b}$} \\
\hline & & Duringd & SE & After ${ }^{\mathrm{e}}$ & SE & $\mathrm{D}-\mathrm{A}$ & SE & $\mathrm{D}-\mathrm{A}$ & SE \\
\hline Experime & 13 & 37 & 19 & 62 & 44 & 332 & 126 & 65 & 8 \\
\hline Control & 10 & 69 & 22 & 54 & 53 & 195 & 152 & 65 & 10 \\
\hline
\end{tabular}

a $\mathrm{D}-\mathrm{A}=$ "During to After" shift.

b D-A = "During to After" overlap.

c Deer exposed to frightening device (experimental) or control.

d During = 6 July 2001-23 July 2001.

e After = 24 July 2001-11 August 2001.
Frightening devices had no effect on the useareas of radiomarked deer (Table 1). The mean size of use-areas of radiomarked deer exposed to experimental or control fields did not differ throughout the study. Thirteen radiomarked deer used experimental fields and 10 used control fields. Size of the use-areas was not influenced by treatment $\left(F_{2,26}=\right.$ $1.00, P=0.380)$, time $\left(F_{1,25}=2.08, P=0.161\right)$, and treatment-by-time interactions $\left(F_{2,25}=1.49, P=\right.$ $0.245)$. Deer continued to use cornfields even if they contained frightening devices. Location of the centers of the use-areas of radiomarked deer exposed to the experimental or control fields did not differ throughout the study $\left(F_{2,25}=0.39, P=0.684\right)$. Regarding use-areas of the 13 radiomarked deer exposed to the deer-activated bio-acoustic device, 7 shifted their use-areas closer to the experimental field, 5 moved away from the field, and 1 did not move toward or away from the field. Regarding use-areas of the 10 deer exposed to control fields, 7 moved toward the control field, 2 moved away, and 1 moved neither away nor toward the control. 
Deer did not alter their use-areas to avoid cornfields that contained frightening devices. Overlaps of chronologically sequenced use-areas for radiomarked deer exposed to the different treatments were not significantly different $\left(F_{2,25}=0.20\right.$, $P=0.818)$. Deer continued to use all cornfields regardless of the treatment.

\section{Discussion}

The data we collected did not support the hypothesis that fields protected with frightening devices would experience less use and damage by deer than control fields. The 4 response variables we measured showed no detectable differences among protected fields and control fields.

We expected that track counts associated with control fields would increase from the "Pretreatment" period to the "Treatment" period as the corn plants grew and produced ears, then decrease over time in the "Post-treatment" period after the ears of corn became less attractive to deer. We also expected that track counts would be lower in experimental fields than control fields during the treatment. This was not the case, however, as track counts in general decreased throughout the study period in experimental and control fields (Figure 2 ). Use of fields by deer may have been influenced by the fact that mature cornfields also provided cover that deer would continue to use even after the silking-tasseling stage. The average track-count indices for experimental fields decreased at a higher rate than for control fields from pretreatment to treatment period, which may show an initial response to the devices.

In similar research, Gilsdorf et al. (2004) reported that track-count indices tended to increase throughout the study period. Results here showed a tendency for track count indices to decrease throughout the study period. Such results may be due to drought conditions that occurred during the summer of 2001. Dry soil contributed to observer difficulty in identifying deer tracks entering or leaving cornfields. In addition, drought may have caused the ears of corn to senesce earlier; therefore, fiber content increased, palatability decreased, and ultimately use by deer decreased.

Although not significantly different, the experimental fields sustained slightly more damage by deer than control fields. The average percentage of damage/plot was 6\% higher in experimental fields than control. One field that was assigned a fright- ening device sustained intense deer damage before the silking-tasseling stage and before the frightening devices were applied. The elevated use of some experimental fields by deer during the "Pretreatment" period may have contributed to higher levels of damage (Figure 2). It may be difficult to break the feeding pattern of deer once it is established or to evaluate a frightening device used for a short time based on damage that occurred between planting and the silking-tasseling stage.

Another possible confounding factor in our study is that the frightening devices protected only portions of 2 sides of the test fields rather than the entire perimeter. Deer that did not walk between the infrared transmitter and receiver could have entered a cornfield without activating the frightening devices. Although we placed the devices in areas we felt would receive the greatest amount of pressure by deer, the devices may have provided more protection if the entire perimeters were protected. The device also may be more effective in small areas of concern such as gardens or highvalue plantings.

The frightening device did not appear to alter use-areas of radiomarked deer enough to deter them from using protected cornfields. Use-areas of deer exposed to a frightening device increased slightly in size ( $\bar{x}=44$ ha, range of 8-84) and centers shifted little $(\bar{x}=158 \mathrm{~m}$, range of $66-455 \mathrm{~m})$. Each deer used $\leq 1$ cornfield in their use-area and did not move to another cornfield after the devices were installed (Table 1). The mean "After" size and shift in location of use-areas of deer exposed to the frightening devices was inflated due to one individual that temporarily moved $2,414 \mathrm{~m}$, resulting in a use-area of 280 ha.

On 5 occasions we saw deer trigger the device, which resulted in deer fleeing from the area. Deer would turn toward the distress calls, listen for 3-5 seconds, then flee from the cornfield or run into the field for protection, suggesting that the sounds frightened them.

When selecting a home-range estimator, researchers should consider the behavior of subject animals, landscape of the study area, and statistical capabilities of the estimator since there is no single "best" estimator for all circumstances (Worton 1995, Shivik and Gese 2000). An optimal sample size for number of locations to estimate a home range is about 50 per animal but may vary from as few as 20 to as many as 200 locations depending on the home-range estimator used (Kernohan et al. 
2001, Leban et al. 2001). In our study we evaluated use-areas over 18-day periods and were concerned with spatial relationships rather than comparing estimator accuracy for inliers and outliers. We used the harmonic mean home-range estimator because it is less sensitive to small sample sizes than are other estimators. The harmonic mean is a special case of the kernel methods (Larkin and Halkin 1994). We believe we selected the most applicable estimator to achieve our objectives.

Animals often react physiologically to alarm and distress calls. Thompson et al. (1968) reported that some starlings (Sturnus vulgaris) exposed to starling distress calls had heart rates over 700 beats/min, which was $130 \%$ above the normal heart rate. Gorenzel and Salmon (1993) reported that crows (Corvus brachyrbynchos) responded to tape-recorded crow distress and alarm calls by taking flight and circling overhead while giving assembly and scolding calls. The crows stopped vocalizing and flew away after the tape was played, leaving the roost empty. Numbers of Canada geese (Branta canadensis) in campgrounds were reduced an average of $71 \%$ with alarm and distress calls (Mott and Timbrook 1988). In another study Canada geese became alert and moved up to $100 \mathrm{~m}$ away from alarm and distress calls but never left the area (Aguilera et al. 1991). Knowledge of potential use of mammalian communication signals is limited. Sprock et al. (1967) reported that a Norway rat (Rattus norvegicus) exposed to rat distress calls spent fewer hours in a sound chamber in which the calls were emitted. Similar reactions may be evident in other mammals (Frings 1964, Sprock et al. 1967, Koehler et al. 1990). We chose deer alarm and distress calls to serve as the innovative stimuli for our frightening device because research using mammalian bio-acoustics is scarce and we felt they had the most potential to deter deer with limited habituation.

Advancements in technology have allowed for improvements in activation systems for frightening devices. Infrared and lasers beams can be used to activate frightening devices, making them operable only in the presence of offending animals. Animalactivated frightening devices are thought to reduce habituation to the stimuli, thus rendering the animal-activated devices more effective than systematic devices over time (Belant et al. 1996).

A similar study was conducted during the same year in Missouri, using a similar frightening device, except that acoustic stimuli included a visual effigy and a variety of sounds rather than strictly alarm and distress calls. The frightening device was effective in reducing deer damage to small ( $0.4 \mathrm{ha})$ plots of soybeans for up to 6 weeks (Beringer et al. 2003).

\section{Management implications}

We suggest additional testing of the deer-activated bio-acoustic device under other conditions, such as high-value crops including fruits and vegetables and in smaller areas that allow for the protection of the entire perimeter of the area. Placing speakers inside the area to be protected rather than on the perimeter may result in the deer leaving the field. The device could also be modified to include a visual stimulus and a variety of acoustic stimuli, which may increase effectiveness. Agricultural producers typically tolerate damage levels of $\leq 10 \%$ of the crop value (Craven et al. 1992). Considering that the prototype devices cost $\$ 600$ to construct and \$40-50 to operate, they may provide limited but cost-effective protection from deer damage, especially in high-value crops. An animal-activated device that incorporates as many stimuli (i.e. acoustic and visual) as possible and one that is inexpensive and relatively maintenance-free may prove to be most applicable for controlling wildlife damage (Koehler et al. 1990, Belant et al. 1996).

Methods for controlling deer damage are limited by proximity to urban areas. Controlled hunting and sharpshooting can be effective but may be difficult to justify in urban areas due to local ordinances and concerns about human health and safety (Jones and Witham 1995, Kuser 1995, Mayer et al. 1995, Kilpatrick et al. 1997). The public supports management, especially nonlethal techniques, to control wildlife causing damage to personal property (Green et al. 1997, Loker et al. 1999, Reiter et al. 1999). Nonlethal devices such as the deer-activated bio-acoustic device may be useful in some rural and urban environments.

Acknowledgments. We thank the University of Nebraska's Integrated Pest Management Program and the National Wildlife Research Center of the United States Department of Agriculture, Animal and Plant Health Inspection Service, Wildlife Services (USDA/APHIS/WS) for funding this research. We also thank L. Klimek, M. Buske, and the rest of the DeSoto National Wildlife Refuge staff for guidance and providing study sites and equipment 
necessary for our research. We thank P. Fiorenelli, S. Gaddis, M. Pipas, and K. Tope for assisting with the damage assessment; T. Gilsdorf and J. Minturn for assisting with the design and construction of the frightening device; and T. Wardle of the Nebraska Forest Service for providing a trailer to transport the tractor. We thank Associate Editor M. Crête, anonymous referees, L. Powell, and M. Hack for their helpful review of the manuscript. This publication is a contribution of the University of Nebraska's Agricultural Research Division, Lincoln, Nebraska, Journal Series No. 14016. The research was supported in part by funds provided through the Hatch Act.

\section{Literature cited}

Aguilera, E., R. L. Knight, and J. L. Cummings. 1991. An evaluation of two hazing methods for urban Canada geese. Wildlife Society Bulletin 19:32-35.

Belant, J. L., T. W. SEAmans, AND C. P. Dwyer. 1996. Evaluation of propane exploders as white-tailed deer deterrents. Crop Protection 15:575-578.

BELANT, J. L.,T.W.SEAMANS,AND L.A.TySON. 1998. Evaluation of electronic frightening devices as white-tailed deer deterrents. Vertebrate Pest Conference 18: 107-110.

Beringer, J., K. C. VerCauteren, and J. J. Millspaugh. 2003. Evaluation of an animal-activated scarecrow and a monofilament fence for reducing deer use of soybean fields. Wildlife Society Bulletin 31:492-498

BOMFORD, M., AND P. H. O'BRIEN. 1990. Sonic deterrents in animal damage control: a review of device tests and effectiveness. Wildlife Society Bulletin 18:411-422.

CONOVER, M. R. 2002. Resolving human-wildlife conflicts. The science of wildlife damage management. Lewis Publishers, Boca Raton, Florida, USA.

CONOVER, M. R., AND D. J. DeCKer. 1991. Wildlife damage to crops: perceptions of agricultural and wildlife professionals in 1957 and 1987. Wildlife Society Bulletin 19:46-52.

Craven, S. R., D. J. Decker, W. F. Siemer, and S. E. Hygnstrom. 1992. Survey use and landowner tolerance in wildlife damage management. Transactions of the North American Wildlife and Natural Resources Conference 57:75-88.

Craven, S. R., And S. E. Hygnstrom. 1994. Deer. Pages D25-D40 in S. E. Hygnstrom, R. M. Timm, and G. E. Larson, editors. Prevention and control of wildlife damage. University of Nebraska Cooperative Extension Service, Lincoln, USA.

Curtis, P. D., C. FitzGerald, AND M. E. Richmond. 1997. Evaluation of the Yard Gard ultrasonic yard protector for repelling white-tailed deer. Eastern Wildlife Damage Management Conference 7:172-176.

Dixon, K. R., AND J. A. Chapman. 1980. Harmonic mean measure of animal activity areas. Ecology 61: 1040-1044.

EldREDGE, J. C. 1935. The effect of injury in imitation of hail damage on the development of the corn plant. Iowa Agricultural Home Economic Experimental Station Resource Bulletin 185.

Engeman, R. M., AND R. T. STERnER. 2002. A comparison of potential labor-saving sampling methods for assessing large mammal damage in corn. Crop Protection 21:101-105.

ENGEMAN, R. M.,AND R.T. SugIHARA. 1998. Optimization of variable area transect sampling using Monte Carlo simulation.
Ecology 79: 1425-1434.

Frings, H. 1964. Sound in vertebrate pest control. Vertebrate Pest Conference 2:50-56.

Gilsdorf, J. M., S. E. Hygnstrom, and K. C.VerCauteren. 2002. Use of frightening devices in wildlife damage management. Integrated Pest Management Reviews 7:29-45.

Gilsdorf, J. M., S. E. Hygnstrom, K. C.VerCauteren, E. E. Blankenship, AND R. M. Engeman. 2004. Propane exploders and Electronic Guards were ineffective at reducing deer damage in cornfields. Wildlife Society Bulletin 32: XXX-XXX (THIS ISSUE).

Gorenzel, W. P, AND T. P. SALMON. 1993. Tape-recorded calls disperse American crows from urban roosts. Wildlife Society Bulletin 21:334-338.

Green, D., G. R.Askins, and P. D.West. 1997. Public opinion: obstacle or aid to sound deer management? Wildlife Society Bulletin 25:367-370.

Hygnstrom, S. E., J. R. Hygnstrom, K. C. VerCauteren, N. S. Foster, S. B. LEMBEZEDER, AND D. J. HAFER. 1992. Effects of chronological deer damage on corn yields. Eastern Wildlife Damage Control Conference 5:65.

JONES, J. M., AND J. H. WiThAM. 1995. Urban deer "problem" solving in Northeast Illinois: an overview. Pages 58-65 in J. B. McAninch, editor. Urban deer: a manageable resource? Proceedings of the symposium of the 55th Midwest Fish and Wildlife Conference. North Central Section of The Wildlife Society, 12-14 December 1993, St. Louis, Missouri, USA.

Kernohan, B. J., R.A. GitZen, And J. J. MillsPaugh. 2001. Analysis of animal space use and movements. Pages 125-166 in J. J. Millspaugh and J. M. Marzluff, editors. Radio tracking and animal populations. Academic Press, San Diego, California, USA.

Kilpatrick, H. J., S. M. Spohr, And G. C. Chasko. 1997. A controlled deer hunt on a state-owned coastal reserve in Connecticut: controversies, strategies, and results. Wildlife Society Bulletin 25: 451-456.

Koehler, A. E., R. E. Marsh, And T. P. SAlmon. 1990. Frightening methods and devices/stimuli to prevent mammal damage-a review. Vertebrate Pest Conference 14: 168-173.

KusER, J. 1995. Deer and people in Princeton, New Jersey, 1971-1993. Pages 47-50 in J. B. McAninch, editor. Urban deer: a manageable resource? Proceedings of the symposium of the 55th Midwest Fish and Wildlife Conference. North Central Section of The Wildlife Society, 12-14 December 1993, St. Louis, Missouri, USA.

LARKIN, R. P.,AND D. HALKIN. 1994. A review of software packages for estimating animal home ranges. Wildlife Society Bulletin 22: 274-287.

Leban, F.A., M. J. Wisdom, E. O. Garton, B. K. Johnson, and J. G. KIE. 2001. Effect of sample size on the performance of resource selection analyses. Pages 297-307 in J. J. Millspaugh and J. M. Marzluff, editors. Radio tracking and animal populations. Academic Press, San Diego, California, USA.

Littell, R. C., G. A. Milliken, W. W. Stroup, AND R. D. Wolfinger. 1996. SAS system for mixed models. SAS Institute, Cary, North Carolina, USA.

LoKer, C.A., D. J. DeCKER, AND S. J. SCHWAGER. 1999. Social acceptability of wildlife management actions in suburban areas: 3 cases from New York. Wildlife Society Bulletin 27: 152-159.

Marchinton R. L.,AND D. H. HiRTH. 1984. Behavior. Pages 129-168 in L. K. Halls, editor. White-tailed deer: ecology and management. Stackpole Books, Harrisburg, Pennsylvania, USA.

Mayer, K. E., J. E. DiDonato, and D. R. McCullough. 1995. California urban deer management: two case studies. Pages 51-57 in J. B. McAninch, editor. Urban deer: a manageable 
resource? Proceedings of the symposium of the 55th Midwest Fish and Wildlife Conference. North Central Section of The Wildlife Society, 12-14 December 1993, St. Louis, Missouri, USA.

McLean, R. A., W. L. SANDERS, AND W. W. Stroup. 1991. A unified approach to mixed linear models. The American Statistician 45:54-64.

MotT, D. F.,AND S. K.Timbrook. 1988. Alleviating nuisance Canada goose problems with acoustical stimuli. Vertebrate Pest Conference 13:301-304.

NOLTE, D. L. 1999. Behavioral approaches for limiting depredation by wild ungulates. Pages 60-70 in K. L. Launchbaugh, K. D. Sanders, and J. C. Mosley, editors. Grazing behavior of livestock and wildlife. Idaho Forest, Wildlife and Range. State bulletin \#70. University of Idaho, Moscow, USA.

Reiter, D. K., M. W. Brunson, AND R. H. SChMidt. 1999. Public attitudes toward wildlife damage management and policy. Wildlife Society Bulletin 27:746-758.

SAS Institute, Inc. 2000. SAS OnLineDoc, Version 8. SAS Institute, Cary, North Carolina, USA.

SAUER, P. R. 1984. Physical characteristics. Pages 73-90 in L. K. Halls, editor. White-tailed deer: ecology and management. Stackpole Books, Harrisburg, Pennsylvania, USA.

Shapiro, C.A.,T.A. Peterson, AND A. D. Flowerday. 1986. Yield loss due to simulated hail damage on corn: a comparison of actual and predicted values. Agronomy Journal 78:585-589.

SHIVIK, J.A.,AND E. M. GESE. 2000. Territorial significance of homerange estimators for coyotes. Wildlife Society Bulletin 28: 940-946.

Sprock, C. M., W. E. Howard, AND F. C. JaCob. 1967. Sound as a deterrent to rats and mice. Journal of Wildlife Management 31:729-741.

Thompson, R. D., C. V Grant, E. W. Pearson, G. W. Corner. 1968. Differential heart rate response to starlings to sound stimuli of biological origin. Journal of Wildlife Management 32: 888-893.

VerCauteren, K. C. 1998. Dispersal, home range fidelity, and vulnerability of white-tailed deer in the Missouri River valley. Dissertation, University of Nebraska, Lincoln, USA.

VORST, J. J. 1986. Assessing hail damage to corn. Institute of Agriculture and Natural Resources, Cooperative Extension Service. University of Nebraska NebGuide 803.

WORTON, B. J. 1995. A convex hull-based estimator of homerange size. Biometrics 51:1206-1215.

WYWIALOWSKI, A. P. 1996. Wildlife damage to field corn in 1993. Wildlife Society Bulletin 24:264-271.

WYWIALOWSKI, A. P., AND R. H. BEACH. 1992. Agricultural producer's estimates of wildlife causing damage in eastern states. Eastern Wildlife Damage Control Conference 5:66.

Jason Gilsdorf (with deer, right) is a wildlife research technician with the School of Natural Resources at the University of Nebraska-Lincoln. He received his B.S. in wildlife from the University of Wisconsin-Stevens Point, and an M.S. in natural resource sciences (wildlife ecology) from the University of Nebraska-Lincoln. Jason's research focuses on habitat use and movements of white-tailed deer and wildlife damage management. He is a member of The Wildlife Society. Scott Hygnstrom (with dogs, left) is a professor in the School of Natural Resources at the University of Nebraska-Lincoln specializing in wildlife damage management. He received his B.S. from the University of Wisconsin-River Falls, M.S. from the University of Wisconsin-Stevens Point, and Ph.D. from the University of Wisconsin-Madison. Scott is a Certified Wildlife
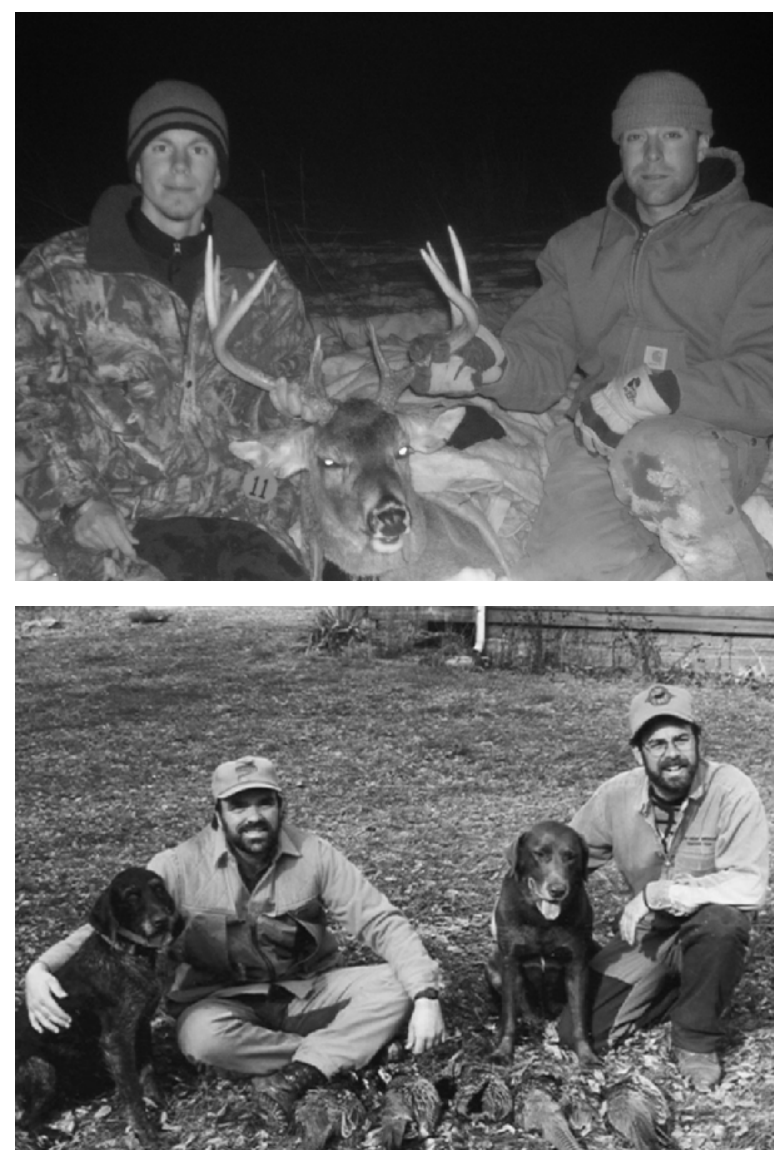

Biologist and is a past-chair of the Wildlife Damage Management Working Group. Kurt VerCauteren (with dogs, right) is the Chronic Wasting Disease project leader for the Wildlife Disease Research Program at the USDA/APHIS/Wildlife Services/National Wildlife Research Center. Kurt received his B.S. from the University of Wisconsin-Stevens Point and M.S. and Ph.D. from the University of Nebraska-Lincoln. Kurt is a Certified Wildlife Biologist and is on the board of TWS's Wildlife Damage Management Working Group. He has served as secretary of the Colorado Chapter of TWS and as president and secretary of the Nebraska Chapter. His current research involves devising means to manage Chronic Wasting Disease in wild and captive cervids. Greg Clements (with deer, left) is a wildlife research technician majoring in fisheries and wildlife at the University of Nebraska-Lincoln. His current research focuses on habitat use and movements of white-tailed deer. Erin Blankenship is an assistant professor in the Department of Statistics at the University of Nebraska-Lincoln. Erin received her B.S. in mathematics from Truman State University and M.S. and Ph.D. in statistics from North Carolina State University. Her interests include nonlinear fixed- and mixed-effects models, environmental statistics, and statistical consulting. Richard (Rick) Engeman is a research biometrician at the National Wildlife Research Center. He received his B.S. and M.S. degrees from Colorado State University in mathematics and statistics, respectively. His Ph.D. is from the University of Colorado Health Sciences Center in biometrics. Rick's research interests include developing statistically valid and practical methods for indexing animal populations, estimating animal damage, and using the information to conduct economic analyses of management approaches

Associate editor: Crête 